DOI: $10.47743 /$ jss-2021-67-4-1

\title{
Cyberspace, the Final Frontier? Concluding and Performing Agreements. Unfair Terms in B2B Adhesion Contracts
}

\author{
Cyberspace, ultima frontieră? Încheierea şi executarea \\ contractelor. Clauze abuzive în contractele de adeziune B2B
}

\section{Carmen Tamara Ungureanu ${ }^{1}$}

\begin{abstract}
If a few years ago the virtual space was a "place” considered exotic for concluding contracts, now it is a common practice. The vast majority of contracts can be concluded online and most of them are adhesion contracts. Adhesion contracts (take-it-or-leave-it) are a consequence of trade modernization and are absolutely necessary. Nevertheless, they carry their own special risks, no matter the adherent's quality, that of a consumer or a professional. One of the risks is that of acceptance by the adherent of unfair terms imposed by the other contractual party. We will not discuss the unfair terms in consumer contracts, but those embedded in B2B contracts. Starting from the relatively recent legislative changes in European law and the laws of certain member states (Germany and France in particular) we will show that the current trend is to sanction abusive clauses/unfair terms in adhesion contracts, irrespective of the contract type, B2C or B2B.
\end{abstract}

Keywords: adhesion contracts; B2B contracts; unfair terms

Rezumat: Dacă în urmă cu câţiva ani spaţiul virtual era un „loc” considerat exotic pentru încheierea contractelor, în prezent este o practică obişnuită. Marea majoritate a contractelor se pot încheia online şi cele mai multe dintre ele sunt contracte de adeziune.Contractele de adeziune (take-it-or-leave-it) reprezintă o consecinţă a modernizării comerţului şi sunt absolut necesare. Acestea ascund, însă, riscuri, indiferent de calitatea aderenţilor, consumatori sau profesionişti. Unul dintre riscuri este acela al acceptării de către aderent a clauzelor abuzive, impuse de cealaltă parte contractantă. Nu vom discuta despre clauzele abuzive din contractele cu consumatorii, ci despre cele încorporate în contractele B2B. Pornind de la modificările legislative relativ recente din legislaţia europeană şi din aceea a anumitor state membre (Germania şi Franţa în special) vom arăta că tendinţa actuală este de a sancționa clauzele abuzive din contractele de adeziune, indiferent de tipul contractelor, B2C sau B2B.

Cuvinte-cheie: contracte de adeziune; contracte B2B; clauze abuzive

${ }^{1}$ Professor PhD, Faculty of Law, "Alexandru Ioan Cuza” University of Iași, e-mail: carmen.ungureanu@uaic.ro. 


\section{Introduction}

If a few years ago the virtual space was a "place" considered exotic for concluding contracts, now it is a common practice. The vast majority of contracts can be concluded online and most of them are adhesion contracts.

Adhesion contracts or, in other words, standard form contracts ${ }^{2}$, are a consequence of trade modernization. "[C]ontracts of adhesion are a welfareenhancing feature of modern commercial life. For firms, the very uniformity and rigidity of such contracts makes them valuable as a means of reducing agency costs and fixing expectations of future obligations. For consumers, not having to bargain is valuable as well"3. Imagine what it would mean to negotiate each contract for buying goods at a supermarket, for public transportation, for online services, for creating an email address or an account on a platform, etc. "The costs of reading, understanding, and bargaining over every term in such contracts would be enormous" 4 .

Due to the frequency of consumer contracts, there is a misconception that the only adhesion contracts would be the $\mathrm{B} 2 \mathrm{C}$ contracts. The truth is that almost any type of contract can be an adhesion one. Thus, adhesion contracts can be contracts concluded by consumers with professionals (consumer contracts or B2C - business-to-consumers), individual employment contracts, insurance contracts, contracts concluded between professionals (B2B - business-to-business), etc. An extreme type of adhesion contract is the so-called smart contract, whose applicability has taken a momentum in the framework of the growing blockchain technology and DLT (distributed ledger technology) ${ }^{5}$.

Not all contracts that can be concluded and performed in the virtual space will be analyzed here, not even all of the adhesion contracts, but only one of the

${ }^{2}$ J. Gordley, In defense of Roman contract law, in P. G. Monateri (ed.), Comparative Contract Law, Edward Elgar Publishing, 2017, ebook, p. 37.

${ }^{3}$ A. Tutt, On the Invalidation of Terms in Contracts of Adhesion, Yale Journal on Regulation, vol. 30, no. 2/2013, p. 442, [Online] at http://digitalcommons.law.yale.edu/yjreg/ vol30/iss2/5, accessed 10.08.2021.

${ }^{4}$ Ibidem.

5 This type of contract will not be discussed in this paper. For the analysis of smart contracts in the legal literature, see, M. Durovic, F. Lech, The Enforceability of Smart Contracts, The Italian Law Journal, vol. 5, no. 2/2019, p. 493 et seq., https://doi.org/ 10.23815/2421-2156.ITALJ, [Online] at https:/www.theitalianlaw journal.it/duroviclech/, accessed 11.11.2021; J. Bacon, J.D. Michels, C. Millard, J. Singh, Blockchain Demystified, Queen Mary School of Law Legal Studies Research Paper No. 268/2017, p. 27, [Oline] at https://ssrn.com/abstract=3091218, accessed 11.11.2021; G. Rühl, Smart (legal) contracts, or: Which (contract) law for smart contracts?, March 10, 2020, in B. Cappiello, G. Carullo (eds.), Blockchain, Law and Governance, Springer, p. 2, [Online] at https://ssrn.com/abstract= 3552004, accessed 11.11.2021. 
risks to which the parties in the adhesion contracts are exposed to will be singled out, namely that of accepting unfair terms or, in other words, abusive clauses ${ }^{6}$.

In this endeavor, the meaning of 'adhesion contract' (1) and that of 'unfair terms' (2) will be first clarified. The need for protection of professional adherents will then be explained (3) and European and national approaches to unfair terms between professionals (4) will be addressed, concluding that the current trend is to protect adherents, regardless of their quality, of consumers or professionals.

\section{The meaning of 'adhesion contract'7}

In European law the concept of adhesion contract is not defined, but it is nevertheless used (for example, in Article 3 of Directive 93/13/EEC on unfair terms in consumer contracts ${ }^{8}$ ), and different types of contracts regulated in certain domains meet the characteristics of the adhesion contract, as it appears in some national legislations.

In the Romanian Civil Code, certain articles were dedicated to the adhesion contract $^{9}$, taking over a part of the regulation in this field of the Civil Code of Québec. The meaning of adhesion contract is set in article 1175 of the Romanian Civil Code, as the contract with the essential clauses imposed or drawn up by one of the parties, on his/her behalf or upon his/her instructions, which are not negotiable, the other party accepting them as they $\operatorname{are}^{10}$.

Considering that the definition is similar to that in article 1379 of the Civil Code of Québec ${ }^{11}$, its comments from the legal literature and the according legal practice will be taken into consideration. Thus, the characterization of a contract as being an adhesion one implies cumulatively meeting two elements: a) the essential clauses of the contract have to be imposed by one of the parties; $b$ ) the

${ }^{6}$ The notions of unfair terms and abusive clauses are going to be used interchangeably in this paper.

${ }^{7}$ C.T. Ungureanu, The Romanian Adherent, Party to the Transnational Adhesion Contract, in Studies of Business Law - Recent Developments and Perspectives, Peter Lang, Berlin, 2013, pp. 263-266.

${ }^{8}$ OJ L 95/29, 21.4.1993, with its subsequent amendments.

${ }^{9}$ The articles from the Civil Code in which there are referrals to the adhesion contracts are: article 1175, article 1269 (2), article 1671 and article 2515.

${ }^{10}$ In the legal literature, it was appreciated that, from the definition of the adhesion contract it can be noted that a contract can be qualified as being an adhesion one, either when the essential clauses were imposed by one of the parties or when they were drawn up by one of the parties; from the final part of the text it can be deduced that there is no adhesion contract unless the essential clauses are imposed to the adherent; see, for this, A.A. Moise, Sources of Obligations, in The New Civil Code. Comments on articles, C. H. Beck Publishing House, Bucharest, 2012, p. 1229.

${ }^{11}$ Article 1379 Civil Code of Québec: « Le contrat est d'adhésion lorsque les stipulations essentielles qu'il comporte ont été imposées par l'une des parties ou rédigées par elle, pour son compte ou suivant ses instructions, et qu'elles ne pouvaient être librement discutées. », [Online] at http://legisquebec.gouv.qc.ca/en/showversion/cs/CCQ-1991?code=se:1379 \&pointInTime $=20170915$, accessed 09.11.2021. 
other party has to find itself in the impossibility of negotiating the contract. It was stated that the nature of the contract or the quality of the parties is not relevant ${ }^{12}$. The imbalance between the contractual parties regarding their economic, legal or informational power does not justify in abstracto considering a contract as an adhesion one; it has to be established if one of the parties was in the impossibility to negotiate the clauses of the contract ${ }^{13}$. It is not sufficient that a contract be drawn up by one of the parties or for her/him by a third party (for example, a lawyer), but it has to be imposed to the other party, to the adherent.

As a consequence, the adherent is always in a position of inferiority towards the stipulant, no matter what his/her quality is, a professional or a contractual party considered vulnerable, in need for protection.

As to the essential character of the contractual clauses, this has to be examined in each particular case, by the court; what is not essential to one contractual party, could be essential to the other one. In the Québec case law, the courts set up in different situations the meaning of 'essential clauses'. For instance, in an intellectual property contract four clauses were considered to be essential: the exclusivity clause, the penalty clause, the amount of money which the artist should receive and the contract period ${ }^{14}$.

The clauses of the adhesion contract are, as a rule, standard clauses (boilerplate clauses) defined in art. 1202 (2) of the Romanian Civil Code as stipulations previously established by one of the parties to be used generally and repeatedly and which are included in the contract without having been negotiated with the other party. It is possible, however, that the adhesion contract also includes clauses that are not „generally and repeatedly” used by the stipulant, but are imposed on certain adherents. The standard clauses, if they fall into any of the types listed in art. 1203 of the Romanian Civil Code are considered unusual clauses or, in other words, surprising terms, which do not produce effects unless they are expressly accepted in writing by the other party ${ }^{15}$.

The terms of the adhesion contract, whether standard or not, could be unfair terms with a content that disadvantages or even harms the adherent.

\section{The meaning of 'unfair terms' in an adhesion contract}

Adhesion contracts hide inside the risk for adherents to accept unfair terms, either because they express their consent without knowing the contractual clauses (often the adherent signs the contract or, to be accurate, ticks an icon without

12 B. Lefebvre, Le contrat d'adhésion, in "La Revue du Notariat", Montréal vol. 105, september 2003, p. 444, https://doi.org/10.7202/1045922ar, [Online] at https:// papyrus. bib.umontreal.ca/jspui/bitstream/1866/1386/1/Contrat\%20d'adhesion.pdf, accessed 18.11.2021.

${ }^{13}$ B. Lefebvre, op.cit, p. 446.

${ }^{14}$ Rousse c. Dion, J.E. 2001-1213 (C.Q.) as cited by B. Lefebvre, op. cit., p. 447, note 24; R. Baudouin, Code civil du Québec annoté, tome II, $14^{\text {th }}$ Edition, Wilson \& Lafleur Itée, 2011, p. 1649 et seq.

${ }^{15}$ For an analysis of unusual clauses, see, I.-F. Popa, „Tirania” clauzelor neuzuale, Revista Română de Drept Privat, no. 1/2016. 
reading the contract), or because, although they know the contract terms, accepts them anyway, being constrained by the need to conclude the contract ${ }^{16}$.

In most cases only two people read the terms of the adhesion contract: the lawyer who drafted the clauses, which are frequently taken from different sources of standard clauses/boilerplate clauses, and he/she may not go through either carefully and include them in the contract because they are part of the common practice in a particular field ${ }^{17}$ and the second person reading them is the adherent's lawyer, who explains to his client what he/she has undertaken through the contract and that there are great chances to not recover the damage suffered.

The notion of an unfair contractual term is defined in the European consumer protection law, in article 3 of Directive 93/13/EEC on unfair terms in consumer contracts, as a contractual term which has not been individually negotiated, if, "contrary to the requirement of good faith, it causes a significant imbalance in the parties' rights and obligations arising under the contract, to the detriment of the consumer". A contractual term should "always be regarded as not individually negotiated where it has been drafted in advance and the consumer has therefore not been able to influence the substance of the term, particularly in the context of a pre-formulated standard contract".

The Directive has been transposed into the legislations of the Member States so that consumers are protected from unfair contract terms, in particular those of adhesion (standard contracts). In Romanian law, the unfair term in contracts concluded between consumers and professionals ${ }^{18}$ is the clause that has not been negotiated directly with the consumer and that creates, by itself or together with other provisions of the contract, a significant imbalance between the rights and obligations of the parties, contrary to the requirements of good faith. The sanction of inserting an abusive clause in the contract is set by the court, on a case-by-case basis. The expression used by the legislator in the law ${ }^{19}$, according to which abusive clauses do not produce effects on the consumer, and the contract continues to bind the parties if it can remain in force without the unfair terms, has been interpreted

16 S. Guillemard, D. É. Onguene Onana, Le contrat d'adhésion : actualités et droit international privé, Les Cahiers de droit, Vol. 48, no. 4/2007, p. 646, https://doi.org/10.7202/ 043948aradresse copiée, [Online] at https://www.erudit.org/ fr/revues/cd1/2007-v48-n4cd3850/043948ar/, accessed 2.11.2021; S. Guillemard, D.É. Onguene Onana, op.cit, p. 646.

17 R. E. Scott, S. J. Choi, M. Gulati, Revising Boilerplate: A Comparison of Private and Public Company Transactions, Wisconsin Law Review, 2020, p. 629, [Online] at https://scholarship.law.duke.edu/faculty_scholarship/4038/, accessed 10.11.2021.

${ }^{18}$ Law no. 193/2000 on abusive clauses in contracts concluded between professionals and consumers, republished in Official Gazette (hereinafter O.G.) no. 543, 03.08.2012.

${ }^{19}$ Article 6 from Law no. 193/2000. 
in the legal literature in the sense that the applicable sanction ${ }^{20}$ is absolute partial nullity ${ }^{21}$.

In the EU law and in the national law of the Member States, as a result of the implementation of European directives, the annulment/ineffectiveness of unfair terms is therefore reserved for consumers ${ }^{22}$. The adherents who are not consumers usually do not enjoy any special protection with regard to unfair terms.

However, the issue of unfair terms in B2B (business-to-business) contracts has been a concern for the European legislator, who in 2011 discussed an instrument developed by the European Commission Expert Group on European Contract Law, which contained proposals on this matter ${ }^{23}$. Article 85 of the instrument provided that ,in contracts between businesses a non-individually-negotiated term is unfair only if it significantly disadvantages the other party and is of such a nature that its use grossly deviates from good commercial practice, contrary to good faith and fair dealing." ${ }^{24}$. In this way, the Expert Group treated the unfair terms in B2B contracts differently, compared to those in consumer contracts (as defined above).

The contractual unfair term in this meaning was included in the proposal for a Regulation on a Common European Sales $\mathrm{Law}^{25}$, in Article 86. However, the

${ }^{20}$ In legislation, in order to indicate the sanction of ineffectiveness of a clause inserted in a contract, invalidly concluded, expressions such as the following can be used: "the clause is deemed unwritten", "the clause is without effect", "the clause is inoperative" and, less often, "the clause is null". All these expressions used in the Romanian legislation were taken from the EU legislation (where, given the diversity of existing sanctions in the Member States, neutral terms were used; an illustrative example is the sanction of non-effect of the abusive clauses of Directive 93/13/EEC of 5 April 1993 on unfair terms in consumer contracts (see, S. Gaudemet, La clause réputée non écrite, Editions Economica, Paris, 2006, pp. 75-76). The definition of these sanctions and the distinction among them are not covered by this paper.

${ }^{21}$ L. Pop, Tratat de drept civil. Obligațiile. Vol. II. Contractul, Universul Juridic Publishing House, Bucharest, 2009, pp. 333-335.

${ }^{22}$ Legal literature abounds in articles and books on this topic, among them: L. Bercea, Acţiunile colective în eliminarea clauzelor abuzive din contractele standard de consum. Cui prodest?, in Revista Română de Drept Privat, no. 3/2013, pp. 24-36; J. Goicovici, Dreptul consumaţiei, Sfera Juridică, Cluj-Napoca, 2006.

${ }^{23}$ M.W. Hesselink, Unfair Terms in Contracts Between Businesses, in J. Stuyck, R. Schulze (eds.), Towards a European Contract Law, Sellier European Law Publishers, 2011, pp. 131-148.

${ }^{24}$ M.W. Hesselink, op. cit., p. 132.

${ }^{25}$ Bruxelles, 11.10.2011 COM (2011) 635 final 2011/0284 (COD), [Online] at https://eurlex.europa.eu/legal-content/RO/TXT/PDF/?uri=CELEX:52011PC0635\&from=EN, accessed 08.08.2021. 
proposal was withdrawn in $2014^{26}$ on the grounds of a new proposal to include ecommerce in the digital single market ${ }^{27}$.

Unfair contractual terms in B2B contracts is an issue discussed in the AngloSaxon law system, as well. In American law, certain clauses within an adhesion contract could be unenforceable/deemed "unconscionable” by applying the unconscionability doctrine ${ }^{28}$. „In contract law, a contract is defined unconscionable when it is unfair or extremely one-sided in favor of the party who has the superior bargaining power. An unconscionable contract can be defined as an agreement that mentally competent people would not enter into and that no fair and honest person would accept"29.

\section{Why would adherents-professionals need protection?}

People in a state of vulnerability need protection. In adhesion contracts adherents are vulnerable, as they are made for various reasons to accept the clauses imposed by the stipulant, elaborated in his/her favor. Legislative protection would result in contract rebalancing, with the contracting parties returning to a certain position of equality ${ }^{30}$.

In any contract one of the parties imposes himself/herself on the other, because there cannot be a perfect balance between the economic, legal, informational, bargaining power of the parties. All the more so in the case of adhesion contracts, the freedom of contract principle suffers, as the adherent has only the freedom to choose between contracting (under the conditions imposed by the other party) and not contracting.

${ }^{26}$ Commission Work Programme 2015, A New Start, Strasbourg, 16.12.2014, COM (2014) 910 final. Annex II: List of withdrawals or modifications of pending proposals, item 60, [Online] at https://ec.europa.eu/info/sites/default/files/cwp_2015_annex_ii_en.pdf, accessed 09.08.2021.

${ }^{27}$ For explanations on the failure of the proposal, K. Norris, Common European Sales Law: A Missed Opportunity or Better Things to Come, in Business Law Review, vol. 37, no. 1/2016, pp. 29-32; M. Király, The Rise and Fall of Common European Sales Law, in Elte Law Journal, no. 2/2015, pp. 31-42, [Online] at https://eltelawjournal.hu/rise-fall-commoneuropean-sales-law/, accessed 08.08.2021.

${ }^{28} \mathrm{We}$ will not analyze the American approach here. For a presentation of the doctrine of unconscionability, see C.A. Rodriguez-Yong, The Doctrines Of Unconscionability And Abusive Clauses: a Common Point Between Civil And Common Law Legal Traditions, Oxford University Comparative Law Forum, 2011, [Online] at https://ouclf.law.ox.ac.uk/thedoctrines-of-unconscionability-and-abusive-clauses-a-common-point-between-civil-andcommon-law-legal-traditions/, accessed 12.08.2021; E. D’Agostino, Contracts of Adhesion Between Law and Economics. Rethinking the Unconscionability Doctrine, Springer, 2015, ebook; N. Browne, L. Biksacky, Unconscionability and the Contingent Assumptions of Contract Theory, Michigan State Law Review, 2013, pp. 212-255, [Online] at https://scholarworks.bgsu.edu/ econ_pub/11/, accessed 12.08.2021.

${ }^{29}$ E. D'Agostino, op. cit., p. 7.

${ }^{30}$ M.W. Hesselink, op. cit., pp. 132-134. 
There are many asymmetries between professionals who enter into contracts, related to various factors, such as: complexity of goods or services which contracting on, experience in contracting and negotiation, understanding the meaning of legal or economic terms, the economic dependence of one professional on the other, etc. For example, imbalances occur in the relationship between a trader and a distributor, between a franchisor and a franchisee, between farmers in distribution chains, and so on. In these cases there is mainly a matter of economic dependence. Contracts characterized by economic dependence are those in which one of the professionals, the adherent, is dependent on a regular, privileged or exclusive relationship with his contractual partner, which has the effect of placing him in a state of dependence and domination, in exchange for his survival on the market ${ }^{31}$.

The professionals, as adherents, are in a state of vulnerability similar to that of consumers. Besides that, in an adhesion contract the adherent is vulnerable, whether he is a consumer or a professional, by the simple fact that he cannot influence the content of the contractual clauses, which are pre-written by the stipulant in his/her favor.

Does a person need protection in this capacity as adherent or does it have to take all the necessary measures and bear the risks of the economic activity in which it has engaged? But if he is economically dependent on the stipulant, does that mean he has a choice between entering into the contract and going bankrupt? If the idea of applying the caveat emptor principle were accepted, without any exception, then implicitly the abuse of power of the professionals as stipulants would be justified and an unfair competition would be considered as representing normality.

The rules on commercial competition are not sufficient to ensure the use of fair trade practices. The objectives of commercial competition law, moreover, are to guarantee fair competition in the market and not to protect the interests of individual competitors ${ }^{32}$. Therefore, legislative intervention in this area seems to be necessary, aiming at restricting the use of unfair terms, ensuring a market characterized by fair competition and economic stability. Abusive clauses can threaten the entire economic system. For example, if the stipulant imposes jurisdiction clauses in favor of a state court or arbitral tribunal, which are

${ }^{31} \mathrm{G}$. Virassamy, Les contrats de dépendance, essai sur les activités professionnelles exercées dans une dépendance économique, Librairie Générale de Droit et de Jurisprudence, Paris, 1986, p. 10.

32 I. Graef, Differentiated Treatment in Platform-to-Business Relations: EU Competition Law and Economic Dependence, in Yearbook of European Law, Vol. 38, no. 1/2019, p. 450, https://doi.org/10.1093/yel/yez008, [Online] at https://research.tilburguniversity.edu/en/ publications/differentiated-treatment-in-platform-to-business-relations-eu-com, accessed 04.08.2021. 
prohibitive for the adherent, in terms of distance, language, costs, this may ultimately lead to the adherent's exit from the market, being unable to recover ${ }^{33}$.

\section{European and national approaches to unfair terms between professionals $^{34}$}

Both in European law (sectoral only) and in the legislation of certain EU Member States, including Germany, France, Belgium ${ }^{35}$, the Netherlands, there have been some relatively recent legislative changes ${ }^{36}$, by which unfair terms in contracts are sanctioned regardless of the type of contract in which they were embedded, thus applying not only to consumer contracts, but also to B2B contracts.

At the European level, Regulation (EU) 2019/1150 on promoting fairness and transparency for business users of online intermediation services ${ }^{37}$, known as the P2B (platform-to-business) Regulation, has been adopted. This Regulation recognizes that online platforms enter into contracts with companies using their services (especially micro, small and medium-sized enterprises) from a position of superiority "which enables them to, in effect, behave unilaterally in a way that can be unfair and that can be harmful to the legitimate interests of their businesses users and, indirectly, also of consumers in the Union'38. The superiority of service providers (online platforms) has the economic dependence as basis; „they might unilaterally impose on business users practices which grossly deviate from good commercial conduct, or are contrary to good faith and fair dealing"39. This way, the definition of the unfair contractual term between professionals/traders is taken from the proposal for a Regulation on a Common European Sales Law, which in article 86.1 (b) provides that: "In a contract between traders, a contract term is unfair for the purposes of this Section only if: (b) it is of such a nature that its use grossly deviates from good commercial practice, contrary to good faith and fair dealing".

It seems that the European legislator "saw" that not only do adherents, as consumers, need protection from unfair terms, but also professionals, as adherents, may need protection when contracting with other professionals in a position of power (economic, financial, informational, etc.). The P2B Regulation could be

33 C. Rinaldo, Beyond Consumer Law - Small Enterprises, Independent Contractors and other Professional Weak Parties, in European Review of Contract Law, vol. 15, no. 2/2019, p. 236, https://doi.org/10.1515/ercl-2019-0012, accessed 20.10.2021.

34 C.T. Ungureanu, Drept internațional privat european în raporturi de comerț internațional, Hamangiu Publishing House, Bucharest, 2021, pp. 33-37.

${ }^{35}$ I. Graef, op. cit, p. 451.

${ }^{36}$ Part of the analysis was taken from the author's article Calificarea europeană a acțiunii în răspundere civilă intentată împotriva unui cocontractant și efectele acesteia. Cauza CJUE C-59/19, in the Scientific Annals of "Alexandru Ioan Cuza" University, Juridical Sciences Series, Tome LXVI/II, 2020, pp. 112-115, [Online] at http://pub.law.uaic.ro/ro/volumepublicate/2020/anale-uaic-tomul-lxvi-tiine-juridice-nr.-2, accessed 19.11.2021.

${ }^{37}$ OJ, L 186/57, 11.7.2019.

${ }^{38}$ Recital 2 from the P2B Regulation.

${ }^{39}$ Idem. 
considered as a first European instrument that raises the issue of protecting professionals who adhere to adhesion contracts concluded with online platforms.

The provisions of the Regulation are overriding mandatory rules ${ }^{40}$, as they apply irrespective of the law otherwise applicable. [article 1(2)]. The sanction of noncompliance with the provisions of the P2B Regulation regarding the terms and conditions (contractual clauses) imposed on the users of the platform is their nullity [article 3(3)].

Another European instrument aimed at protecting agricultural and food professionals is Directive (EU) 2019/633 on unfair trading practices in business-tobusiness relationships in the agricultural and food supply chain ${ }^{41}$, which was to be transposed in the Member States by 1 May $2021^{42}$ and which aims at "combating practices that grossly deviate from good commercial conduct, that are contrary to good faith and fair dealing and that are unilaterally imposed by one trading partner on another" [article 1(1)]. Thus, the Directive's goal is formulated almost identically to article 86 of the Regulation proposal on a Common European Sales Law.

The core motivation for the protection of professionals, parties to contracts in the agricultural and food supply chain, is the imbalances in their bargaining power $^{43}$, which can lead the more important and powerful trading partners to using unfair trade practices to their advantage; for example, they may "impose an unjustified and disproportionate transfer of economic risk from one trading partner to another" or "impose a significant imbalance of rights and obligations on one trading partner" 44 .

In certain European national legislations, professionals also benefit from protection against unfair terms in B2B contracts.

Germany and France have in recent years drafted rules on unfair terms applicable to contracts between professionals with a view to making their

${ }^{40}$ For details on overriding mandatory rules, see C.T. Ungureanu, Overriding Mandatory Rules in International Commercial Contracts Dispute Resolution. A Romanain perspective, Cuadernos de Derecho Transnacional (Octubre 2020), Vol. 12, No 2, pp. 784-794, https://doi.org/10.20318/cdt.2020.5630, [Online] at https://e-revistas.uc3m.es/index.php/ CDT/about/editorialPolicies\#custom-0, accessed 19.11.2021.

${ }^{41}$ JO L111/59, 25.4.2019.

${ }^{42}$ At 18.11.2021, Romania has not yet transposed the directive. Nevertheless, a draft Law (PL-x no. 178/2021 on unfair commercial practices between enterprises in the agricultural and food supply chain, [Online] at http://www.cdep.ro/ pls/proiecte/upl_pck2015. proiect?cam $=2 \&$ idp=19294, accessed, 18.11.2021) from June 3rd, 2021 is following the legislative procedure.

${ }^{43}$ H. Schebesta, K.P. Purnhagen, B. Keirsbilck, T. Verdonk, Unfair Trading Practices in the Food Chain: Regulating Right?, 2018, http://dx.doi.org/10.2139/ssrn.3267118, [Online] at https://ssrn.com/abstract=3267118, accessed 11.11.2021.

${ }^{44}$ Recital 1 from the Directive. 
regulations attractive on the "market" of the law applicable to international contracts ${ }^{45}$.

Germany has enacted rules since $1976^{46}$ on judicial control over unfair terms in B2B contracts ${ }^{47}$, integrated into the Civil Code in 2002. According to article 307 (1) of the German Civil Code, the clauses of standard B2B contracts do not produce effects if, contrary to good faith, they unreasonably benefit to the party who proposed them, including if they are unclear and difficult to understand ${ }^{48}$. These provisions have general applicability, regardless of the quality of the contracting parties, regardless of their bargaining power. The party that pre-drafted the contractual clauses must prove that the negotiation of the clauses has taken place (so the burden of proof is reversed), in order to avoid the application of the protective rules ${ }^{49}$. In legal practice, it is considered that the negotiation of a clause took place only when the adherent was available for negotiation and the stipulant gave him the opportunity to influence the content of the clause as to protect his economic interests; the bargaining power of the parties is not a criterion that the courts take into account ${ }^{50}$.

The German approach to unfair terms in B2B contracts has been criticized in the legal literature, where it was considered that the protection of the adherent has gone too far, producing negative consequences. For instance, companies of German nationality, with great economic power, have chosen to change their headquarters, migrating to Switzerland, where the legislation does not contain such invasive provisions on the control of unfair terms ${ }^{51}$.

In France, after the amendment of the Civil Code in 2018, the adhesion contract is defined in art. 1110, as the contract containing a set of non-negotiable clauses, predetermined by one of the parties ${ }^{52}$ (the negotiable contract being the one in which its terms are negotiable).

${ }^{45}$ F.P. Patti, Unfair Terms Control in Business-to-Business Contracts, in The Italian Law Journal, vol. 5, no. 2/2019, pp. 584-585, https://doi.org/10.23815/2421-2156.ITALJ, [Online] at https://www.theitalianlawjournal.it/patti/, accessed 19.11.2021.

46 Act concerning the Regulation of Standard Contract Terms, with comments by O. Sandrock, The Standard Terms Act 1976 of West Germany, in The American Journal of Comparative Law, vol. 26, no. 4/1978, p. 551, https://doi.org/10.2307/840058.

${ }^{47}$ F.P. Patti, op. cit., p. 585.

48 [Online] at https://www.gesetze-im-internet.de/englisch_bgb/englisch_bgb.html\# p0915, accessed 08.11.2021. For comments see, H. Schulte-Nölke, No Market for 'Lemons': On the Reasons for a Fudicial Unfairness Test for B2B Contracts, in European Review of Private Law, no. 2/2015, pp.195-216.

${ }^{49}$ C. Rinaldo, op. cit., p. 230.

${ }^{50}$ Ibidem.

${ }^{51}$ Idem, p. 231.

${ }^{52}$ Article 1110 French Civil Code: «Le contrat de gré à gré est celui dont les stipulations sont négociables entre les parties. Le contrat d'adhésion est celui qui comporte un ensemble de clauses non négociables, déterminées à l'avance par l'une des parties. ", [Online] at https://www.legifrance.gouv.fr/codes/section_lc/LEGITEXT000006070721/LEGISCTA0000 06090271/\#LEGISCTA000006090271, accessed 08.11.2021. 
In the legal literature it has been stated that it is not necessary for the qualification of a contract as negotiable that the clauses have been negotiated, but only to be susceptible to negotiation ${ }^{53}$. Determining the non-negotiable nature of a contractual clause could be very difficult in legal practice ${ }^{54}$.

The ineffectiveness of unfair contractual terms has become a rule in French law, as art. 1171 of the French Civil Code ${ }^{55}$ reads that, in an adhesion contract, any non-negotiable clause, predetermined by one of the parties, which creates a significant imbalance between the rights and obligations of the contracting parties, is deemed unwritten.

Also in France, following the amendment of the Commercial Code in $2019^{56}$, article L $442-1, \mathrm{I} .2^{\circ}$ stipulates that any professional who carries out production, distribution or service activities and who imposes or tries to impose obligations on the other contracting party (also a professional), which creates a significant imbalance between the rights and obligations of the parties, is held liable and is obliged to repair the damage thus caused. According to art. L 442-4 I., the injured party (or anyone justifying an interest) may request the competent court to cease the abusive practices and repair the damage. The victim of abusive practices may request the nullity of contractual clauses or illegal contracts and the recovery of contributions ${ }^{57}$. These rules are not an absolute novelty for the French law. In 2008 an article was introduced in the Commercial Code, article 442-6, I, which stipulated the liability of the professional for subjecting or attempting to subject a trading partner to obligations creating a significant imbalance between the rights and obligations of the contractual parties ${ }^{58}$.

In this context, the French legal literature ${ }^{59}$ has raised the issue of the new amendments clarity, as the provisions of the Civil Code and of the Commercial

53 A.W. Grumberg, F. Barrière, G. Roche, Contrats d'adhésion et clauses abusives : un clair-obscur pour la pratique sociétaire, in Fusions \& Acquisitions Magazine, novembredécembre 2018, p. 106.

${ }^{54}$ Ibidem.

55 Article 1171 French Civil Code: «Dans un contrat d'adhésion, toute clause non négociable, déterminée à l'avance par l'une des parties, qui crée un déséquilibre significatif entre les droits et obligations des parties au contrat est réputée non écrite. L'appréciation du déséquilibre significatif ne porte ni sur l'objet principal du contrat ni sur l'adéquation du prix à la prestation. », [Online] at https://www.legifrance.gouv.fr/codes/ article_lc/ LEGIARTI000036829836/, accessed 06.11.2021.

56 Modified by the Ordonnance $n^{\circ} 2019-359$ du 24 avril 2019 - article 2, [Online] at https://www.legifrance.gouv.fr/codes/id/LEGIARTI000038414278/2020-11-

28/?isSuggest=true, accessed 02.11.2021.

57 [Online] at https://www.legifrance.gouv.fr/codes/id/LEGIARTI000038414278/202011-28/?isSuggest=true, accessed 02.11.2021.

58 The original text: «[...]de soumettre ou de tenter de soumettre un partenaire commercial à des obligations créant un déséquilibre significatif dans les droits et obligations des parties» as referred to in X. Henry, Clauses abusives dans les contrats commerciaux : état des lieux dix ans après, in Af Contrats d'affaires : concurrence, distribution, Dalloz, 2018, p. 370.

${ }^{59}$ X. Henry, op. cit., pp. 372-373. 
Code overlap, making it difficult to discern, all the more in legal practice, whether the general rule applies (from the Civil Code) or the special rule (from the Commercial Code).

In Belgium, after the amendment of the Economic Law Code in 2019, the unfair terms in $\mathrm{B} 2 \mathrm{~B}$ contracts ${ }^{60}$ were prohibited, through the provisions of article VI.91/3, in force since December $1,2020^{61}$. According to it, any contractual clause, concluded between undertakings (professionals), is abusive if, alone or in conjunction with one or more clauses, creates a manifest imbalance between the rights and obligations of the parties. The unfairness of the clause should be assessed on the basis of the nature of the products as object of the contract and on all circumstances existing at the time of the conclusion of the contract, on the general economics of the contract, the applicable commercial customs, and on all other contractual clauses or on another contract which the contract in question depends on and on the clarity and comprehensibility of the clause. The following two articles list the unfair terms and the presumed (irrefutably) unfair terms (article VI.91/4, article VI.91/5); art. VI.91/6 sets out the sanction for unfair terms in B2B contracts, namely the (partial) nullity ${ }^{62}$.

Under Dutch law, the unfair standard terms are regulated in the Civil Code ${ }^{63}$, in article 6:231-6:247, some of the provisions being of general applicability, and others being intended only for consumer contracts ${ }^{64}$.

In Romanian law, so far, the only rule for unfair contractual terms between professionals is found in Law no. 72/2013 on measures to combat the delay in the performance of obligations to pay sums of money resulting from contracts concluded between professionals and between them and contracting authorities ${ }^{65}$. According to article 12, if the time limit for payment or the level of interest or additional damages are manifestly unfair for the debtor, then that certain clause is

${ }^{60}$ For an analysis see, D. Philippe, Les clauses abusives dans les relations B2B, 2019, [Online] at https://philippelaw.eu/wp-content/uploads/2019/08/Clauses-abusive4.pdf, accessed 06.11.2021.

${ }^{61}$ [Online] at http://www.ejustice.just.fgov.be/cgi_loi/loi_a1.pl?language=fr\&la=F\&cn= 2013022819\&table_name $=$ loi\&caller $=$ list $\& \mathrm{~F}=\&$ fromtab $=$ loi\&tri $=\mathrm{dd} \% 20 \mathrm{AS} \% 20 \mathrm{RANK} \& \mathrm{rech}=1$ \&numero=1\&sql=\%28text\%20contains $\% 20 \% 28 \% 27 \% 27 \% 29 \% 29 \#$ Art.VI.1, accessed 02.11.2021.

62 Article VI.91/6 Economic Law Code: «Toute clause abusive est interdite et nulle. Le contrat reste contraignant pour les parties s'il peut subsister sans les clauses abusives», [Online] at http://www.ejustice.just.fgov.be/cgi_loi/loi_a1.pl?language $=$ fr\&la=F\&cn $=2013022819 \&$ table_name $=$ loi\&caller $=$ list $\& \mathrm{~F}=\&$ fromtab $=$ loi \&tri $=\mathrm{dd} \% 20 \mathrm{AS} \% 20 \mathrm{RANK} \& \mathrm{rech}=1 \&$ numero $=1$ \&sql=\%28text\%20 contains\%20\%28\%27\%27\%29\%29\#Art.VI.1, accessed 02.11.2021.

63 [Online] at http://www.dutchcivillaw.com/civilcodebook066.htm, accessed 10.11.2021.

${ }^{64}$ For an analysis see, A. Radonjić, Unfair Contract Terms in SMEs in BW and draft CC of Serbia, in Foreign Legal Life, 2017, p. 239 et seq.

${ }^{65}$ O.G. no. $182,02.04 .2013$. 
considered abusive and is struck by absolute nullity (article 15. 1), which may lead to compensation (article 15.2) ${ }^{66}$.

\section{Conclusions}

"The massive emergence of technology in the realm of contracts and contract law has been interpreted mainly in terms of transaction costs reduction, since technology is instrumental to form agreements in a more expeditious way, regardless of the distance between contractors" 67 .

The adhesion contract is an absolutely necessary tool in today's global trade. Beyond the benefits it offers, the contracting parties must also bear its inherent risks. However, a legislative intervention is necessary, with the main purpose of restoring the balance of power and thus the rights and obligations of the contracting parties and thereby ensuring a predictable market, characterized by fair trade and fair competition. The current rules show that the way forward has already been set at the European level. There is an expectation that the European instruments on unfair clauses in B2B contracts will give momentum at national level, in all member states, as well.

\section{References}

Bacon, J., Michels, J.D., Millard, C., Singh, J., Blockchain Demystified, Queen Mary School of Law Legal Studies Research Paper No. 268/2017

Baudouin, R., Code civil du Québec annoté, tome II, 14 ${ }^{\text {th }}$ Edition, Wilson \& Lafleur Itée, 2011

Bercea, L., Acţiunile colective în eliminarea clauzelor abuzive din contractele standard de consum. Cui prodest?, in Revista Română de Drept Privat, no. 3/2013, pp. 24-36

Browne, N., Biksacky, L., Unconscionability and the Contingent Assumptions of Contract Theory, Michigan State Law Review, 2013, pp. 212- 255

D'Agostino, E., Contracts of Adhesion Between Law and Economics. Rethinking the Unconscionability Doctrine, Springer, 2015, ebook

Durovic, M., Lech, F., The Enforceability of Smart Contracts, The Italian Law Journal, vol. 5, no. 2/2019, pp. 493-511, https://doi.org/10.23815/2421-2156.ITALJ

Gaudemet, S., La clause réputée non écrite, Editions Economica, Paris, 2006

Goicovici, J., Dreptul consumaţiei, Sfera Juridică, Cluj-Napoca, 2006

Gordley, J., In defense of Roman contract law, in Monateri, P. G. (ed.), Comparative Contract Law, Edward Elgar Publishing, 2017

Graef, I., Differentiated Treatment in Platform-to-Business Relations: EU Competition Law and Economic Dependence, in Yearbook of European Law, Vol. 38, no. 1/2019, pp. 448-499, https://doi.org/10.1093/yel/yez008

Granieri, M., Technological contracts, in Monateri, P.G., (ed.), Comparative Contract Law, Edward Elgar Publishing, 2017

${ }^{66}$ For details see, Ghe. Piperea, Clauze și practici abuzive în relațiile dintre profesioniști, 2013, [Online] at https://www.juridice.ro/256771/clauze-si-practici-abuzive-in-relatiiledintre-profesionisti.html, accessed 02.11.2021.

${ }^{67}$ M. Granieri, Technological contracts, in P.G. Monateri (ed.), Comparative Contract Law, Edward Elgar Publishing, 2017, ebook, p. 408. 
Grumberg, A.W., Barrière, F., Roche, G., Contrats d'adhésion et clauses abusives : un clairobscur pour la pratique sociétaire, in Fusions \& Acquisitions Magazine, novembredécembre 2018

Guillemard, S., Onguene Onana, D.É., Le contrat d'adhésion : actualités et droit international privé, Les Cahiers de droit, Vol. 48, no. 4/2007, pp. 635-680. https://doi.org/10.7202/ 043948aradresse copiée

Henry, X., Clauses abusives dans les contrats commerciaux : état des lieux dix ans après, in $A \mathcal{F}$ Contrats d'affaires : concurrence, distribution, Dalloz, 2018

Hesselink, M.W., Unfair Terms in Contracts Between Businesses, in Stuyck, J., Schulze, R. (eds.), Towards a European Contract Law, Sellier European Law Publishers, 2011, pp. 131148

Király, M., The Rise and Fall of Common European Sales Law, in Elte Law Journal, no. 2/2015, pp. 31-42

Lefebvre, B., Le contrat d'adhésion, in „La Revue du Notariat”, Montréal vol. 105, September 2003, pp. 439-490, https://doi.org/10.7202/1045922ar

Moise, A.-A., Sources of Obligations, in The New Civil Code. Comments on articles, C. H. Beck Publishing House, Bucharest, 2012

Norris, K., Common European Sales Law: A Missed Opportunity or Better Things to Come, in Business Law Review, vol. 37, no. 1/2016, pp. 29-32

Patti, F.P., Unfair Terms Control in Business-to-Business Contracts, in The Italian Law Journal, vol. 5, no. 2/2019, pp. 581-611, https://doi.org/10.23815/2421-2156.ITALJ

Philippe, D., Les clauses abusives dans les relations B2B, 2019

Piperea, Ghe., Clauze şi practici abuzive în relaţiile dintre profesionişti, 2013

Pop, L., Tratat de drept civil. Obligaţiile. Vol. II. Contractul, Universul Juridic Publishing House, Bucharest, 2009

Popa, I.-F., „Tirania” clauzelor neuzuale, Revista Română de Drept Privat, no. 1/2016

Radonjić, A., Unfair Contract Terms in SMEs in BW and draft CC of Serbia, in Foreign Legal Life, 2017, pp. 239-251

Rinaldo, C., Beyond Consumer Law - Small Enterprises, Independent Contractors and other Professional Weak Parties, in European Review of Contract Law, vol. 15, no. 2/2019, pp. 227-250, https://doi.org/10.1515/ercl-2019-0012,

Rodriguez-Yong, C.A., The Doctrines Of Unconscionability And Abusive Clauses: a Common Point Between Civil And Common Law Legal Traditions, Oxford University Comparative Law Forum, 2011

Rühl, G., Smart (legal) contracts, or: Which (contract) law for smart contracts?, March 10, 2020, in Cappiello, B., Carullo, G. (eds.), Blockchain, Law and Governance, Springer

Sandrock, O., The Standard Terms Act 1976 of West Germany, in The American Journal of Comparative Law, vol. 26, no. 4/1978, pp. 551-572, https://doi.org/10.2307/840058,

Schebesta, H., Purnhagen, K.P., Keirsbilck, B., Verdonk, T., Unfair Trading Practices in the Food Chain: Regulating Right?, 2018, pp. 690-700, http://dx.doi.org/10.2139/ssrn.3267118,

Schulte-Nölke, H., No Market for 'Lemons': On the Reasons for a fudicial Unfairness Test for B2B Contracts, in European Review of Private Law, no. 2/2015, pp.195-216

Scott, R.E., Choi, S.J., Gulati, M., Revising Boilerplate: A Comparison of Private and Public Company Transactions, Wisconsin Law Review, 2020, pp. 629-655

Tutt, A., On the Invalidation of Terms in Contracts of Adhesion, Yale Journal on Regulation, vol. 30, no. 2/2013, pp. 439-474

Ungureanu, C.T., The Romanian Adherent, Party to the Transnational Adhesion Contract, in Studies of Business Law - Recent Developments and Perspectives, Peter Lang, Berlin, 2013, pp. 261-285 
Ungureanu, C.T., Drept international privat european în raporturi de comerţ international, Hamangiu Publishing House, Bucharest, 2021

Ungureanu, C.T., Overriding Mandatory Rules in International Commercial Contracts Dispute Resolution. A Romanain perspective, Cuadernos de Derecho Transnacional (Octubre 2020), Vol. 12, No 2, pp. 784-794, DOI: https://doi.org/10.20318/cdt.2020.5630

Virassamy, G., Les contrats de dépendance, essai sur les activités professionnelles exercées dans une dépendance économique, Librairie Générale de Droit et de Jurisprudence, Paris, 1986 